\title{
Differences and Commonalities in Physical, Chemical and Mineralogical Properties of Zanzibari Geophagic Soils
}

\author{
Sera L. Young • M. Jeffrey Wilson • Stephen Hillier • \\ Evelyne Delbos $\cdot$ Said M. Ali $\cdot$ Rebecca J. Stoltzfus
}

Received: 21 June 2009 /Revised: 29 September 2009 / Accepted: 23 October 2009 /Published online: 12 January 2010

(C) The Author(s) 2010. This article is published with open access at Springerlink.com

\begin{abstract}
The function of human geophagy has long been questioned. We sought to test hypotheses concerning its potential physiological effects through analysis of soils and patterns in geophagy behavior. Eleven samples of geophagic soils consumed by pregnant women on Pemba Island, Zanzibar, Tanzania, were characterized according to their color, texture, major element chemistry, trace element chemistry, bulk mineralogy, and clay mineralogy. An epidemiological study $(N=2367)$ and ethnographic interviews $(N=57)$ on Pemba yielded information about geophagic behaviors and sociodemographic and biological characteristics of those who consumed earth. The soils varied widely in color, ranging from light red to white through various shades of brown and yellow, and texture ranged from clay to sand. Major element chemistry of the soils also varied greatly; most were low in $\mathrm{Fe}$ and $\mathrm{Ca}$. Trace elements, whether of biological or non-biological significance, were uniformly
\end{abstract}

\section{S. L. Young $(\varangle)$}

University of California Davis Medical Center,

Ticon II, 2516 Stockton Blvd.,

Sacramento, CA 95817, USA

e-mail: slyo@ucdavis.edu

e-mail: sera@younglucks.com

S. L. Young $\cdot$ R. J. Stoltzfus

Division of Nutritional Sciences, Cornell University,

Ithaca, NY 14853, USA

M. J. Wilson $\cdot$ S. Hillier $\cdot$ E. Delbos

Macaulay Land Use Research Institute, Craigiebuckler,

Aberdeen, Scotland AB15 8QH, UK

S. M. Ali

Public Health Laboratory-Ivo de Carneri, Chake Chake,

Pemba Island, Zanzibar, Tanzania low when compared with normal ranges of mineral soils. The sole commonality among the samples is that all clay fractions were dominated by a kaolin mineral: kaolinite, halloysite, or a mixture of both. Geophagy behavior also varied greatly, with one major exception: a greater proportion of pregnant women $(7.1 \%)$ and young children $(4.5 \%)$ consumed earth than non-pregnant women $(0.2 \%)$ or men $(0 \%)$. The presence of kaolin mineral in all samples, its palliative and detoxifying properties, and the highest prevalence of geophagy among those most biologically vulnerable suggest that geophagy may be a protective behavior.

Keywords Pica $\cdot$ Geophagy $\cdot$ Nutrition · Detoxification . Africa $\cdot$ Pregnancy $\cdot$ Mineralogy $\cdot$ Health

\section{Introduction}

Geophagy, the purposeful consumption of earth, has long been a source of fascination and puzzlement. Geophagy is a specific type of pica, which is defined as the craving and subsequent consumption of non-food substances. The motivation and consequences of this behavior remain unclear. Geophagy has been documented in many human cultures (Laufer 1930; Anell and Lagercrantz 1958) and throughout the animal kingdom (Jones and Hanson 1985; Kreulen 1985; Krishnamani and Mahaney 2000). It is a very old practice; the first written account of geophagy was by Hippocrates in the $4^{\text {th }}$ century BCE (Hippocrates 1849), but archaeological evidence suggests it dates back to Homo habilis (Clark 2001).

There are three major groups of hypotheses concerning the physiological causes of pica: hunger, micronutrient 
deficiency, and protection from toxins and pathogens (Young et al. 2008).

1. The hunger hypothesis posits that people consume nonfood substances because they do not have anything else to eat (Laufer 1930).

2. The micronutrient deficiency hypothesis posits that people with micronutrient deficiencies eat non-food substances in an attempt to increase micronutrient intake of Fe (Hunter 1973), Zn (Smith and Halsted 1970), or Ca (Wiley and Katz 1998). Another version of this hypothesis is that a micronutrient deficiency causes disturbed taste sensitivities or malfunctioning of appetite-regulating brain enzymes that cause non-food substances to become appealing (von Bonsdorff 1977). In this scenario, pica is a consequence of micronutrient deficiency, but not an attempt to remedy it.

3. The protection hypothesis states that pica is motivated by an attempt to mitigate the harmful effects of plant chemicals or microbes (Johns 1986; Profet 1992). It is proposed that pica substances protect by either adsorbing pathogens and toxins within the gut lumen or by coating the surface of the intestinal endothelium, thereby rendering it less permeable to toxins and pathogens. According to this hypothesis, overt gastrointestinal distress, which can be the result of exposure to either toxins or pathogens (Simjee 2007), also trigger pica. Additionally, this hypothesis implies that pica substances would be ingested during periods of rapid growth, i.e., the times of greatest need for protection from toxins and microbes. Under this hypothesis, childhood and pregnancy, especially early pregnancy [which is the critical period of organogenesis (Moore and Persaud 1998)], are the periods when pica most likely would occur (Flaxman and Sherman 2000). Pregnant women, who are immunologically suppressed (Formby 1995; Fessler 2002), also may need protection from substances that would normally be harmless.

A limited number of studies have tested these hypotheses, fewer have studied the health status of those practicing pica, and rarer still are studies that have correctly examined the physical, chemical, and mineralogical nature of the soils consumed. In reviewing previous analytical work done on geophagic samples, there are a number of limitations that deserve special attention.

Most published chemical analyses of geophagic earths are not useful for testing the nutritional hypothesis because they are confined typically to the total elemental content, without consideration of the extent to which these elements are biologically available (Wilson 2003; Young et al. 2008). Human gut $\mathrm{pH}$ varies from $\mathrm{pH} 1-2$ in the stomach to $\mathrm{pH} 7-8$ in the small intestine, the site of the bulk of nutrient absorption. This fluctuation has major consequences for the bioavailability of elements, and must be considered when drawing conclusions about nutritional benefits.

Second, the amounts of the soils consumed need to be precisely specified; previous researchers have made calculations about intake based on amounts reported from another study, even if that study took place on a different continent, several decades in the past, or in a different age group (e.g., Hunter 1973; Smith et al. 1998).

Third, although it is critical to establish the mineralogy of geophagic samples, especially in relation to the protection hypothesis, previous studies have been vague in the characterization of their mineralogy. For example, halloysite is identified specifically as the main clay mineral in the soils consumed by humans (Aufreiter et al. 1997) and various primates (Mahaney et al. 1993, 1995a, b, 1997; Aufreiter et al. 2001), although Wilson (2003) concluded that the identification of the clay mineral in these papers was ambiguous. The distinction between different kaolin minerals could be important, as kaolinite and halloysite have different particle morphologies (flat platy vs. tubular or spheroidal), which could affect their dispersion/flocculation behavior (Itami and Fujitani 2005), as well as their viscosity and flow characteristics (Yuan and Murray 1997). These properties could be significant in affecting the ability of the clays to coat the gut wall, thereby acting as a barrier to harmful chemicals and microorganisms (Allen and Leonard 1985) and as a stimulant to mucus secretion (Leonard et al. 1994; Theodorou et al. 1994; Gonzalez et al. 2004). Additionally, it may be inferred from some studies of geophagic soils that animals and humans can distinguish halloysitic from kaolinitic soils (Wilson 2003), and knowledge of the exact mineralogy of the soil clays would provide useful information for testing this inference.

In this work, we attempted to increase our understanding of geophagy by a careful characterization of the physical, chemical, and mineralogical properties of 11 samples of consumed earth and then link it to epidemiological and ethnographic data on geophagy behavior. We performed these analyses to identify commonalities that may yield clues to the physiological motivation for the selection and consumption of these materials.

\section{Methods and Materials}

Study Site and Sample Collection Pemba was chosen as an appropriate research site because geophagy is a wellestablished practice there (Young and Ali 2005). Pemba is the second largest island in the Zanzibar archipelago located $50 \mathrm{~km}$ off the coast of Tanzania. The archipelago is part of the ancient Miocene Rufiji/Ruvu delta, and most 
of Pemba is underlain by alluvial formations of Miocene age (Stockley 1942). Similar Miocene alluvial formations host the Pugu kaolinite deposits to the west of Dar es Salaam on the East African mainland. In general, the culture and ecology of Pemba are similar to the rest of coastal East Africa (Middleton 2004).

The geophagic earths for analysis were selected based on results from a large epidemiological study of maternal anaemia and pica in an obstetric population conducted between 2004 and $2006(N=2367)$. Additionally, in-depth interviews about pica were conducted with a sample of 57 individuals who had professed their pica behavior. Participants in in-depth interviews were either pregnant participants in the larger study or resident in a study participant's household. Four respondents were male, and recounted their pica behaviors during childhood.

The 4 types of earth consumed in Pemba are known in Swahili as udongo, mchanga, vitango pepeta and ufue (Fig. 1). Udongo is a fine reddish-brown clayey earth that is found close to the surface or in termitaria, and is used in making structures like house walls. Mchanga is the sandiest of the earths eaten, and is collected close to the surface. It is often exposed during the construction of wells or latrines. Vitango pepeta (also called vitango mlima) consists of large soft light-colored chunks of earth, and is obtained from closer to the surface of the earth than ufue. Ufue is much whiter than udongo and is found by digging from 5 to $50 \mathrm{~cm}$ into the earth's surface. The terms ufue and vitango pepeta are frequently used interchangeably by consumers.

In the large epidemiological study, women were asked about their pica behavior in two questions: if they ate udongo and if they ate vitango pepeta or ufue. Mchanga was not inquired about because it was consumed far less frequently. The interviews with those who had engaged in pica lasted from 30-75 min, and covered the many pica materials consumed in Pemba, including the 4 earths. A number of other pica substances are consumed on Pemba, including uncooked rice, charcoal, ash, ice, chalk, and ground shell, but are beyond the scope of this paper (Young 2008).

During interviews, participants were asked how samples were identified, collected, stored, and prepared, as well as about the attractiveness of various qualities, e.g., color, texture, flavor. After the interview, a Pemban fieldworker and/or an author (SLY) accompanied participants to the source of the pica substance if they were still engaging in pica. The consumer then collected precise amounts of the materials they consumed, as well as a large amount for subsequent analysis. Of the 57 participants in in-depth interviews, 26 had eaten udongo, 10 had eaten ufue, 13 had eaten vitango pepeta, and 2 had eaten mchanga.

The samples chosen for laboratory analysis were selected to reflect the frequency of consumption reported of each type of earth in the interviews. In this study, five udongo samples ( 2 from house walls and 3 from soil exposures), two ufue samples (both soil exposures), three vitango pepeta samples (all soil exposures) and one mchanga sample (soil exposure) were characterized (Table 1). The study would have been strengthened by the analysis of undesirable samples, i.e., samples that were not considered suitable for consumption. This will be rectified in subsequent studies.

Sample analysis The color of the samples was established objectively by reference to a Munsell chart, which describes colors in order of their hue (actual color), value (degree of lightness), and chroma (strength of color). Soil pH measurements were made by an electrometric method that used glass-calomel electrodes on soil suspensions in a soil: water ratio of 1:2.5 following the procedure for agricultural soils outlined by Peech (1965). Particle size analysis was made by laser light scattering (diffraction) by using a Malvern Mastersizer 2000.

Determination of both the major and minor elements in the geophagic samples was done by X-ray fluorescence analysis (XRF). This is the method of choice for inorganic materials because the instrumentation is widely available and has become the standard method for the analysis of major and trace elements of rocks following the procedures developed by Norrish and Hutton (1969) and Leake et al. (1969). XRF analysis is performed on pressed-powder discs and involves no pre-treatment other than a simple crushing and milling procedure.

The mineralogy of the geophagic materials was determined by X-ray diffraction (XRD) methods. Bulk samples were micronized in water in a McCrone mill, and the resulting slurries spray dried as described by Hillier (1999). XRD patterns were obtained from the spray dried random

Fig. 1 The four geophagic earths on Pemba Island, Zanzibar. From left to right: udongo, mchanga, vitango pepeta and ufue

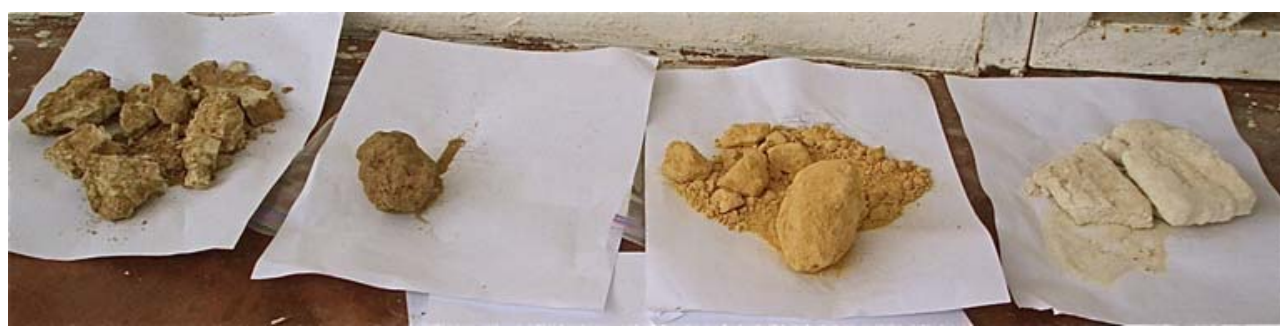


Table 1 Geophagic behavior on Pemba Island, Tanzania, based on 57 in-depth interviews

\begin{tabular}{|c|c|c|c|c|}
\hline & Udongo $(N=26)^{\mathrm{a}}$ & Ufue $(N=10)$ & Vitango pepeta $(N=13)$ & Mchanga $(N=2)$ \\
\hline Who collects material & Self (20); bought in store (1) & Self (6); other relatives (2) & Self (11); other relatives (2) & Self (2) \\
\hline Frequency of collection & $\begin{array}{l}\text { More than once daily (8); once } \\
\text { daily (13); once weekly (2); } \\
\text { once monthly (1) }\end{array}$ & $\begin{array}{l}\text { Once daily (3); once } \\
\text { weekly (4); once } \\
\text { monthly (1) }\end{array}$ & Once weekly (10) & Once daily \\
\hline Distance from home & $1-30 \min$ & $10-120 \mathrm{~min}$ & $5-60 \mathrm{~min}$ & From own home \\
\hline Site & $\begin{array}{l}\text { House wall (10); bought in } \\
\text { store (1); Agricultural fields (4); } \\
\text { "anywhere it's found" (5) }\end{array}$ & $\begin{array}{l}\text { Agricultural fields (4); } \\
\text { digging "anywhere it's } \\
\text { found" (4) }\end{array}$ & $\begin{array}{l}\text { Agricultural fields (3); } \\
\text { hills (7) }\end{array}$ & Most sands are acceptable \\
\hline Preparation & $\begin{array}{l}\text { Sun-dried (4); brushed off (3); } \\
\text { rinsed with water (1); ground (1); } \\
\text { eaten as found (8) }\end{array}$ & $\begin{array}{l}\text { Sun-dried (2); eaten as } \\
\text { found ( } 8 \text { ) }\end{array}$ & $\begin{array}{l}\text { Baked (2); sun-dried (5); } \\
\text { brushed off ( } 3 \text { ) }\end{array}$ & $\begin{array}{l}\text { Dried (1); filtered through } \\
\text { cloth (1) }\end{array}$ \\
\hline Prior to consumption & $\begin{array}{l}\text { Nausea (5); excess salivation (2); } \\
\text { no particular feeling, just a } \\
\text { craving (7) }\end{array}$ & $\begin{array}{l}\text { No particular feeling, just } \\
\text { a craving (5) }\end{array}$ & - & - \\
\hline $\begin{array}{l}\text { Mean frequency of } \\
\text { consumption per } \\
\text { day (range) }\end{array}$ & $2.75(1-10)$ & $2.5(1-4)$ & $4.3(1-20)$ & $2-3$ \\
\hline $\begin{array}{l}\text { Mean amount consumed } \\
\text { per day in } g \text { (range) }\end{array}$ & $71.4(31.3-151.2)$ & $62(40.7-90.5)$ & $53.3(18.4-96.8)$ & 180.2 \\
\hline $\begin{array}{l}\text { Participants' description } \\
\text { of flavor }\end{array}$ & $\begin{array}{l}\text { Sharp, sour }(u k a l i)(5) \text {, } \\
\text { appealing }(10)\end{array}$ & Sharp, sour (ukali ) (7) & Sharp, sour (ukali) (12) & None \\
\hline $\begin{array}{l}\text { Participants' description } \\
\text { of smell }\end{array}$ & Very appealing (13) & Very appealing (2) & Similar to udongo (1) & \\
\hline Reminds them of... & $\begin{array}{l}\text { Smoke of woodfire (2); perfume (1); } \\
\text { uncooked rice (2); cement (1); } \\
\text { baobab candy (ubuyu) (1) }\end{array}$ & $\begin{array}{l}\text { Raw rice frying (1); fruit } \\
\text { juice (1); sour (ukali) } \\
\text { candy (1) }\end{array}$ & $\begin{array}{l}\text { Sour oranges (1), lime (2) } \\
\text { lemon (2), unripe mango (2), } \\
\text { partially broken raw rice (1), } \\
\text { baobab candy }(\text { ubuyu) }(1)\end{array}$ & Fried flour \\
\hline $\begin{array}{l}\text { Reason for cessation } \\
\text { of eating }\end{array}$ & $\begin{array}{l}\text { No longer craved it after } \\
\text { pregnancy (11) }\end{array}$ & $\begin{array}{l}\text { No longer craved it after } \\
\text { pregnancy (6); husband } \\
\text { made her (2) }\end{array}$ & $\begin{array}{l}\text { No longer craved it after } \\
\text { childhood (3); pregnancy (6) }\end{array}$ & $\begin{array}{l}\text { No longer craved it after } \\
\text { pregnancy (2) }\end{array}$ \\
\hline Other & $\begin{array}{l}\text { Causes anaemia (10); good only } \\
\text { if pregnant (10) }\end{array}$ & $\begin{array}{l}\text { Causes anaemia (7); good } \\
\text { only if pregnant (5); } \\
\text { reduces nausea (1) }\end{array}$ & $\begin{array}{l}\text { Causes anaemia (6); good only } \\
\text { if pregnant }(6) \text {; good any } \\
\text { time (2); addictive (1); } \\
\text { reduces nausea (2) }\end{array}$ & $\begin{array}{l}\text { Good only if pregnant (1); } \\
\text { never good (1) }\end{array}$ \\
\hline
\end{tabular}

${ }^{a}$ Not all participants discussed all facets of their geophagic behavior, so the information in each cell does not always sum to the number of respondents

powder samples by scanning from 2 to $75^{\circ} 2 \Theta$, in 0.02 steps, counting for 2 seconds per step on a Siemens D5000, using Co $\mathrm{K} \alpha$ radiation, selected by a diffracted beam monochromator. Bulk mineralogical composition was determined by a full pattern fitting reference intensity ratio method as described in detail in Omotoso et al. (2006). For further characterization of the clay minerals, $<2$ micron clay fractions were separated from the bulk samples by sedimentation, and dried down onto glass slides. The resulting oriented preparations were scanned on the D5000 diffractometer, from $2-45^{\circ} 2 \Theta$, with $0.02^{\circ}$ steps, counting for 1 second per step, in the air-dried state, following solvation with ethylene glycol by a vapor pressure method and after heating to $300^{\circ} \mathrm{C}$ for 1 hour (Wilson 1987).

Identification of certain clay minerals requires the use of supplementary treatments. Distinguishing halloysite from kaolinite is done through the rapid formation of an intercalation complex with formamide (Churchman et al. 1984). Clay fractions sedimented onto glass slides were examined before and after treatment with formamide to determine the presence of halloysite. These samples were run on a Panalytical X-pert Pro diffractometer, using Nifiltered $\mathrm{Cu} \mathrm{K} \alpha$ radiation with an X-celerator position sensitive detector. Both the air-dried and the subsequently formamide-saturated clay samples were scanned from 2 $45^{\circ} 2 \Theta$, the total scan taking approximately 7 minutes to complete. Formamide treated specimens were scanned 30 minutes after contact with formamide.

Coherent fragments of the materials were mounted onto standard SEM stubs using carbon paint as the adhesive coated with gold. The prepared samples were analyzed by using a Philips XL30 Field Emission Scanning Electron Microscope (FEG-SEM) operating at an accelerating voltage of $20 \mathrm{kV}$. Characterisation of the various minerals was aided by Energy Dispersive Spectroscopy (EDS), which provides an elemental composition of the material analyzed. The EDS detector is equipped with an ultra-thin window that allows detection of elements down to carbon. 


\section{Results}

Geophagy in Pemba There was great variety in the collection and consumption of soils (Table 1). Most participants collected their own soils. There were many sites from which they could be obtained, including the walls of houses, agricultural fields, and hills. Some soils were prepared carefully by heating or cleaning, while others were eaten as found. Most consumers were not able to explain why they had cravings for earth, although a few mentioned nausea and excess salivation. The amounts consumed ranged from 18.4 to $180.2 \mathrm{~g}$, and the frequency of daily consumption ranged from 1 to 20 times. Consumers frequently were enthusiastic about liking the smell and taste of the soils, but in non-specific ways. Many answers to inquiries about what they liked about it were variations of "It's just so good!". To better understand the smell and taste they experienced, we asked if there were items that the soil reminded them of.

One clear commonality in behavior is that most geophagy occurs during pregnancy. Of the 2,367 pregnant women interviewed, $169(7.1 \%)$ stated that they had eaten earth in the course of their current pregnancy. Of children $2-5$ years old, $4.5 \%$ engaged in geophagy, $0.2 \%$ of nonpregnant women engaged in geophagy, and no adult men or elderly men or women engaged in pica (Young 2008). No data are available on the behavior of 5-18 year olds. The marked relationship between geophagy and pregnancy was reinforced by participants' comments; many of them ceased craving earth after giving birth and thought that geophagy was "good" only if pregnant (Table 1).

Physical Characteristics Macroscopic Appearance Although the geophagic materials typically are described as "soils", a more accurate description for some would be "saprolites" in that they resemble decomposed and easily disaggregated rock, such as that often found at the base of soil profiles developed by in situ weathering (Table 2). Colors were highly variable, ranging from white to different shades of brown and red. Large textural differences also were apparent, with udongo and mchanga samples being sandy, whereas the ufue and vitango pepeta ones were more clay-rich. The latter appeared to consist of weathered shale or clay, while udongo and mchanga probably represented alluvial sandy material.

pH and Clay Content There was a surprisingly large range of $\mathrm{pH}$ values and proportion of clay and non-clay fractions (Table 3). Alkaline $\mathrm{pH}$ values characterized the udongo and mchanga samples, with one sample (835) yielding a $\mathrm{pH}$ of

Table 2 Color and macroscopic description of 11 geophagic samples from Pemba

\begin{tabular}{|c|c|c|c|}
\hline Sample number & Name & Munsell color & Description \\
\hline 818 & Udongo & Very pale brown (10YR $8 / 3)$ & $\begin{array}{l}\text { Coarse blocky structure; sandy texture; contains } \\
\text { fragments of carbonized wood; slakes immediately } \\
\text { in water. }\end{array}$ \\
\hline 832 & Udongo (house) & Light yellowish brown $(2.5 \mathrm{Y} 6 / 3)$ & $\begin{array}{l}\text { Sandy material containing white inclusions and } \\
\text { organic matter; slakes immediately in water. }\end{array}$ \\
\hline 835 & Udongo (house) & Dark grayish brown $(10 \mathrm{YR} 4 / 2)$ & $\begin{array}{l}\text { Sandy material received in crushed disaggregated } \\
\text { state; some white grains observed. }\end{array}$ \\
\hline 839 & Udongo & Light brownish gray $(2.5 \mathrm{Y} 6 / 2)$ & $\begin{array}{l}\text { Blocky, slightly indurated sandy material; porous } \\
\text { structure with some rootlets; slakes immediately } \\
\text { in water. }\end{array}$ \\
\hline 849 & Udongo (house) & Light red $(2.5 \mathrm{YR} 6 / 6)$ & $\begin{array}{l}\text { Coarse blocky decomposed material of silty } \\
\text { texture; light and porous; slakes immediately } \\
\text { in water. }\end{array}$ \\
\hline 833 & Ufue & White $(5 Y$ 8/1) & Clayey sand; disperses easily but doesn't slake. \\
\hline 845 & Ufue & $\begin{array}{l}\text { White }(7.5 \text { YR } 8 / 1) \text { with pinkish } \\
\text { white }(7.5 \text { YR } 8 / 2) \text { variegations }\end{array}$ & $\begin{array}{l}\text { Soft decomposed clayey material; very coarse } \\
\text { blocky; disperses easily but doesn't slake. }\end{array}$ \\
\hline 834 & Vitango pepeta & $\begin{array}{l}\text { Reddish yellow }(7.5 \mathrm{YR} 7 / 6) \text { with } \\
\text { some red patches }(10 \mathrm{R} 4 / 6) \text {, others } \\
\text { pinkish white }\end{array}$ & $\begin{array}{l}\text { Coarse blocky material, soft and decomposed; } \\
\text { strongly variegated and patchy in color; } \\
\text { clayey/silty texture. }\end{array}$ \\
\hline 812 & Vitango pepeta & $\begin{array}{l}\text { Pale whitish yellow }(2.5 \mathrm{Y} 8 / 3) \\
\text { with yellowish }(10 \mathrm{YR} 8 / 8) \text { mottles }\end{array}$ & $\begin{array}{l}\text { Coarse platy structure; weathered shale; clayey; } \\
\text { disperses easily but doesn't slake immediately. }\end{array}$ \\
\hline 842 & Vitango pepeta & $\begin{array}{l}\text { White }(7.5 \text { YR } 8 / 1) \text { with pink }(7.5 \text { YR } 8 / 2) \\
\text { patches on weathered surfaces }\end{array}$ & $\begin{array}{l}\text { Soft decomposed clayey material; coarse crumbs } \\
(>10 \mathrm{~mm}) \text { and medium blocks }(10-20 \mathrm{~mm}) \\
\text { disperses easily but doesn't slake. }\end{array}$ \\
\hline 838 & Mchanga & Pale yellowish $(2.5 \mathrm{YR} 7 / 3)$ & Fine sandy material. \\
\hline
\end{tabular}


Table $3 \mathrm{pH}$ and particle size analysis (\%) data of 11 geophagic samples from Pemba

\begin{tabular}{llrrrc}
\hline Sample number & Material & $\mathrm{pH}\left(\mathrm{H}_{2} \mathrm{O}\right)$ & $<2 \mu \mathrm{m}$ & $2-20 \mu \mathrm{m}$ & $20-2000 \mu \mathrm{m}$ \\
\hline 818 & Udongo (field) & 7.20 & 8.2 & 7.5 & 84.2 \\
832 & Udongo (house) & 7.62 & 11.0 & 11.7 & 77.3 \\
835 & Udongo (house) & 10.44 & 12.8 & 11.9 & 75.3 \\
839 & Udongo (field) & 8.17 & 6.5 & 5.3 & 88.1 \\
849 & Udongo (field) & 4.72 & 13.8 & 7.9 & 78.3 \\
833 & Ufue & 5.02 & 4.8 & 15.6 & 79.6 \\
845 & Ufue & 4.95 & 25.9 & 12.3 & 61.8 \\
834 & Vitango pepeta & 4.94 & 22.9 & 25.2 & 51.9 \\
812 & Vitango pepeta & 4.80 & 33.6 & 31.6 & 34.8 \\
842 & Vitango pepeta & 4.54 & 17.6 & 23.0 & 59.4 \\
838 & Mchanga & 8.45 & 0.7 & 1.4 & 97.9
\end{tabular}

10.4. This sample came from a house wall to which lime may have been added. In contrast, the ufue and vitango pepeta materials were distinctly acidic with $\mathrm{pH}$ values in the 4.54-5.02 range. Analysis of the clay contents confirmed the impression gained from the assessment of texture, with the mchanga sample containing $<1 \%$ clay in contrast to vitango pepeta with $23-34 \%$ clay.

Chemical Characteristics. Major Elements Both udongo and mchanga samples were very siliceous; total silica contents ranged from 77 to $94 \%$ and with correspondingly low alumina and ferric oxide contents (Table 4). Values for alkalis and alkaline earths were variable. In contrast, the ufue and vitango pepeta samples were less siliceous and more aluminous. In the former, ferric oxide contents were comparable to those of udongo, and alkalis and alkaline earths showed a slightly smaller range of values. The vitango pepeta samples, however, were more iron-rich than any of the samples, with ferric oxide ranging from 1.56 to $8.06 \%$.

Trace Elements Total trace element contents of the geophagic soils (Table 5) usually were lower than the range of values found for mineral soils with $<5 \%$ organic matter derived from all types of parent materials, as assessed by Mitchell (1964). Not all trace elements analyzed are of biological significance from either a nutritional or toxicity point of view, but for the sake of completeness all results are shown. Trace elements of interest in the context of human nutrition, $\mathrm{Co}, \mathrm{Cu}, \mathrm{I}$, and $\mathrm{Zn}$, are all in the low or normal range when compared to the usual range in mineral soils. The same is true of trace elements such as $\mathrm{As}$ and $\mathrm{Pb}$, which are associated with toxicity.

Table 4 Bulk chemical (major element) analyses in geophagic samples ${ }^{1}$

\begin{tabular}{|c|c|c|c|c|c|c|c|c|c|c|c|}
\hline \multirow[b]{2}{*}{ Sample number } & \multicolumn{5}{|l|}{ Udongo } & \multicolumn{2}{|l|}{ Ufue } & \multicolumn{3}{|c|}{ Vitango pepeta } & \multirow{2}{*}{$\begin{array}{l}\text { Mchanga } \\
838\end{array}$} \\
\hline & 818 & 832 & 835 & 839 & 849 & 833 & 845 & 834 & 812 & 842 & \\
\hline $\mathrm{SiO}_{2}$ & 90.97 & 89.07 & 81.45 & 93.49 & 77.02 & 71.58 & 78.61 & 61.61 & 52.08 & 54.05 & 94.48 \\
\hline $\mathrm{TiO}_{2}$ & 0.45 & 0.37 & 0.29 & 0.39 & 0.63 & 0.15 & 0.24 & 0.92 & 0.60 & 0.38 & 0.21 \\
\hline $\mathrm{Al}_{2} \mathrm{O}_{3}$ & 7.58 & 7.75 & 7.92 & 5.04 & 16.13 & 19.78 & 17.78 & 23.20 & 32.30 & 34.58 & 3.12 \\
\hline $\mathrm{Fe}_{2} \mathrm{O}_{3}{ }^{1}$ & 0.75 & 0.88 & 0.74 & 0.73 & 2.72 & 0.84 & 0.46 & 8.06 & 5.74 & 1.56 & 0.57 \\
\hline $\mathrm{MnO}$ & 0.01 & 0.01 & 0.04 & 0.02 & 0.01 & 0.00 & 0.01 & 0.01 & 0.01 & 0.01 & 0.01 \\
\hline $\mathrm{MgO}$ & 0.14 & 0.18 & 0.47 & 0.17 & 0.25 & 0.20 & 0.17 & 0.70 & 1.16 & 0.74 & 0.13 \\
\hline $\mathrm{CaO}$ & 0.18 & 0.77 & 2.97 & 0.14 & 0.04 & 0.17 & 0.06 & 0.11 & 0.04 & 0.04 & 1.79 \\
\hline $\mathrm{K}_{2} \mathrm{O}$ & 0.60 & 0.33 & 1.83 & 0.32 & 0.14 & 2.12 & 0.05 & 0.34 & 0.72 & 0.30 & 0.33 \\
\hline $\mathrm{Na}_{2} \mathrm{O}$ & 0.03 & 0.01 & 0.76 & 0.04 & 0.00 & 0.44 & 0.03 & 0.00 & 0.06 & 0.00 & 0.05 \\
\hline $\mathrm{P}_{2} \mathrm{O}_{5}$ & 0.01 & 0.04 & 0.09 & 0.02 & 0.00 & 0.01 & 0.00 & 0.02 & 0.02 & 0.00 & 0.02 \\
\hline Sum & 100.7 & 99.42 & 96.56 & 100.4 & 96.94 & 95.31 & 97.41 & 94.96 & 92.73 & 91.65 & 100.7 \\
\hline $\mathrm{LOI}^{2}$ & 0 & 0.44 & 3.22 & 0 & 2.84 & 5.14 & 2.15 & 4.87 & 7.12 & 8.01 & 0 \\
\hline
\end{tabular}

${ }^{1}$ All Fe expressed as ferric

${ }^{2}$ LOI-loss on ignition is calculated by difference from $100 \%$ oxides, not measured LOI 
Table 5 Trace element contents (ppm) of 11 Pemban geophagic soils and usual content of trace elements in mineral soils

\begin{tabular}{|c|c|c|c|c|c|c|c|c|c|c|c|c|}
\hline \multirow[b]{2}{*}{ Sample number } & \multicolumn{5}{|c|}{ Udongo } & \multicolumn{2}{|c|}{ Ufue } & \multicolumn{3}{|c|}{ Vitango pepeta } & \multirow{2}{*}{$\begin{array}{l}\text { Mchanga } \\
838\end{array}$} & \multirow[t]{2}{*}{ Usual Mineral Soil Content } \\
\hline & 818 & 832 & 835 & 839 & 849 & 833 & 845 & 834 & 812 & 842 & & \\
\hline As & 4 & 3 & 2 & 2 & 5 & 3 & 1 & 11 & 7 & 2 & 2 & $1-80$ \\
\hline $\mathrm{Ba}$ & 195 & 105 & 99 & 67 & 54 & 795 & 23 & 72 & 66 & 53 & 120 & $100-6000$ \\
\hline $\mathrm{Ce}$ & 15 & 17 & 7 & 16 & 23 & 13 & 8 & 61 & 27 & 19 & 17 & - \\
\hline Co & 1 & 1 & 1 & 2 & 0 & 3 & 1 & 0 & 2 & 2 & 0 & $1-80$ \\
\hline $\mathrm{Cr}$ & 77 & 47 & 42 & 37 & 86 & 82 & 63 & 190 & 130 & 123 & 29 & $7-1000$ \\
\hline $\mathrm{Cu}$ & $<2$ & $<2$ & $<2$ & $<2$ & $<2$ & $<2$ & $<2$ & $<2$ & 8 & $<2$ & $<2$ & $3-100$ \\
\hline $\mathrm{Ga}$ & 6 & 7 & 7 & 5 & 17 & 19 & 17 & 26 & 22 & 26 & 3 & $10-100$ \\
\hline I & 5 & 9 & 5 & 7 & 20 & 3 & 8 & 10 & 3 & 9 & 4 & $2-8$ \\
\hline $\mathrm{La}$ & 8 & 7 & 6 & 7 & 6 & 9 & 8 & 34 & 13 & 9 & 5 & - \\
\hline $\mathrm{Nb}$ & 10 & 10 & 9 & 10 & 13 & 7 & 9 & 16 & 12 & 9 & 8 & - \\
\hline $\mathrm{Ni}$ & $<2$ & $<2$ & $<2$ & $<2$ & $<2$ & $<2$ & $<2$ & $<2$ & $<2$ & $<2$ & $<2$ & $7-800$ \\
\hline $\mathrm{Pb}$ & 12 & 25 & 9 & 10 & 11 & 20 & 7 & 22 & 16 & 13 & 15 & $3-120$ \\
\hline $\mathrm{Rb}$ & 10 & 6 & 24 & 6 & 5 & 40 & 1 & 12 & 22 & 8 & 5 & $12-900$ \\
\hline $\mathrm{Sr}$ & 32 & 32 & 123 & 16 & 14 & 115 & 9 & 21 & 15 & 12 & 43 & $70-1000$ \\
\hline Th & 4 & 3 & 2 & 3 & 4 & 2 & 3 & 9 & 5 & 3 & 2 & - \\
\hline $\mathrm{U}$ & 0 & 0 & 1 & 1 & 1 & 1 & 0 & 2 & 1 & 1 & 0 & - \\
\hline $\mathrm{V}$ & 15 & 16 & 18 & 14 & 50 & 31 & 20 & 120 & 111 & 72 & 8 & $12-800$ \\
\hline $\mathrm{Y}$ & 9 & 9 & 8 & 9 & 9 & 8 & 8 & 15 & 9 & 9 & 8 & - \\
\hline $\mathrm{Zn}$ & 12 & 37 & 24 & 9 & 14 & 14 & 4 & 26 & 39 & 29 & 44 & $10-500$ \\
\hline $\mathrm{Zr}$ & 420 & 291 & 240 & 316 & 384 & 58 & 125 & 446 & 88 & 159 & 218 & $80-3000$ \\
\hline
\end{tabular}

${ }^{a}$ According to Mitchell (1964), for iodine according to Goldschmidt (1954)

Mineralogical Characteristics. Bulk Soil Analysis Mineral analyses of the bulk soils (Table 6) were reasonably consistent with the results of bulk chemical analysis (Table 4). The udongo and mchanga samples were quartzrich with contents ranging from $69-92 \%$ and corresponding closely with $\mathrm{SiO}_{2}$ values. In contrast, the clay-rich vitango pepeta samples contained smaller amounts of quartz (4$35 \%)$ and higher kaolin contents (58-95\%) corresponding to their lower $\mathrm{SiO}_{2}(52-62 \%)$ and higher $\mathrm{A}_{12} \mathrm{O}_{3}(23-35 \%)$ values. The ufue samples occupied a position intermediate between udongo and vitango pepeta with respect to quartz and kaolin contents. The main iron oxide mineral in the geophagic soils was goethite $[\mathrm{FeO}(\mathrm{OH})]$ rather than hematite $\left(\mathrm{Fe}_{2} \mathrm{O}_{3}\right)$, with vitango pepeta samples being the most goethitic $(8-11 \%)$ and correspondingly having the highest ferric oxide content $\left(1.6-8.2 \% \mathrm{Fe}_{2} \mathrm{O}_{3}\right)$. There is a general correspondence between amounts of calcite and $\mathrm{K}$-feldspar, particularly at the high end of the range, with $\mathrm{CaO}$ and $\mathrm{K}_{2} \mathrm{O}$ values, respectively.

Clay Mineral Analyses Clay fractions of the geophagic soils were all dominated by kaolin-type minerals (Table 6). Representative XRD traces of the clay fractions from the various geophagic soils are shown in Fig. 2. In determining the relative kaolinite/halloysite contents of the soils, an initial assessment was made by comparing the intensities of the basal reflection at $\sim 10 \AA$, due to the formation of the formamide/halloysite complex with the basal reflection at $\sim 7 \AA$, which represents the uncomplexed kaolinite mineral. From this, it was evident that kaolinite was dominant in 5

Table 6 Relative kaolinite/halloysite contents in the clay fractions of the geophagic soils as assessed from visual inspection of the XRD patterns before and after formamide treatment

\begin{tabular}{|c|c|c|c|c|c|c|c|c|c|c|c|}
\hline \multirow[t]{2}{*}{ Mineralogy } & \multicolumn{5}{|l|}{ Udongo } & \multicolumn{2}{|l|}{ Ufue } & \multicolumn{3}{|c|}{ Vitango pepeta } & \multirow{2}{*}{$\begin{array}{l}\text { Mchanga } \\
838\end{array}$} \\
\hline & 818 & 832 & 835 & 839 & 849 & 833 & 845 & 834 & 812 & 842 & \\
\hline Kaolinite/ Halloysite & $\mathrm{K}$ dom. ${ }^{\mathrm{a}}$ & $\mathrm{K} \approx \mathrm{H}$ & $\mathrm{K}$ dom. & $\mathrm{K} \approx \mathrm{H}$ & $\mathrm{K}$ dom. & H dom. & $\mathrm{K}$ dom. & $\mathrm{K}$ dom. & $\mathrm{H}$ dom. & $\mathrm{H}$ dom. & $\mathrm{H}>\mathrm{K}$ \\
\hline
\end{tabular}

${ }^{\mathrm{a}}$ Dom. $=$ dominant 


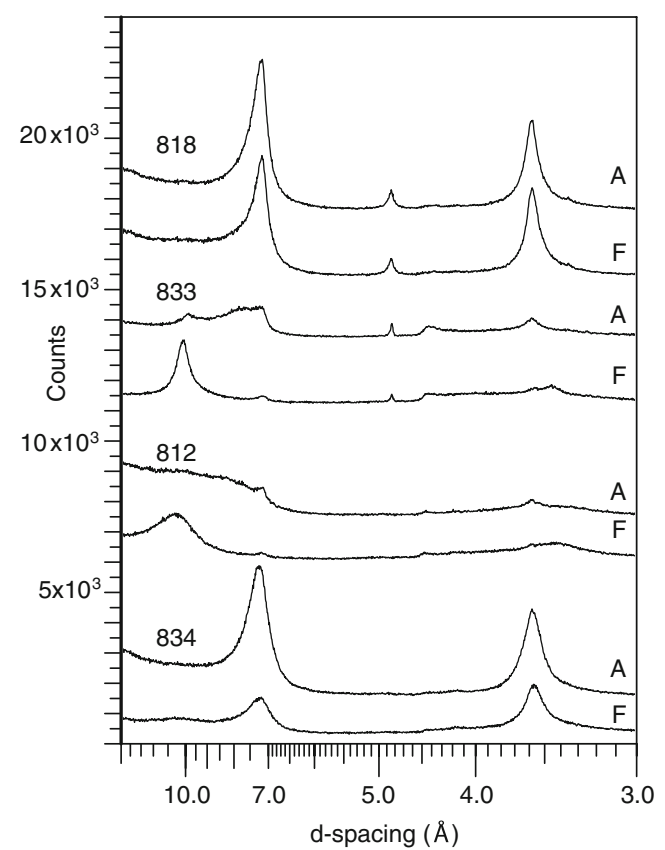

Fig. 2 XRD pattern of the air-dried (A) and formamide-treated (F) clay fractions. Udongo soil (sample 818) showing dominance of kaolinite (strong peak at $7 \AA \hat{\text { ) }}$ over halloysite (weak peak at $10 \AA \hat{\text { ) }}$ after formamide. A small amount of gibbsite is indicated (peak at $4.85 \AA$ ). Two Ufue soil (sample 833) showing dominance of halloysite (strong peak at $10 \AA$ )

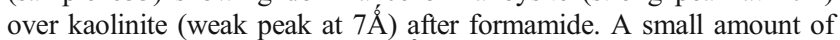
gibbsite is indicated (peak at 4.85Á)..Vitango pepeta soil (sample 812) showing dominance of halloysite (strong peak at 10 ̊́) over kaolinite (weak peak at $7 \AA \dot{~ a f t e r}$ formamide). Other features of these patterns suggest that this clay may be interstratified with smectite, Vitango pepeta soil (sample 834) showing dominance of kaolinite (strong peak

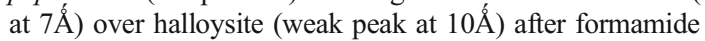

of the 11 samples, halloysite was dominant in 3 samples and sub-dominant in 1 sample (Table 6). In 2 samples, there were roughly equal amounts of both minerals. Both ufue and vitango pepeta samples could be either kaolinite dominant or halloysite dominant. Udongo tended to be kaolinite dominant whereas mchanga was more halloysitic. Quantification of the two minerals by a full pattern fitting method yielded results that were consistent with this initial assessment (Table 7), apart from sample 812 that had special features concerning mixed layering. Most clays also contained minor to trace amounts of gibbsite $\left(\mathrm{Al}(\mathrm{OH})_{3}\right)$, a mineral characteristic of highly weathered soils.

SEM Observations Geophagic materials examined by SEM included one sample of udongo (818), one of ufue (833), and two of vitango pepeta $(812,834)$ (Fig. 3). At low magnification, the udongo sample was found to consist of dense masses of aggregated clay arranged in a sub-parallel fashion that coated and bound together the majority sandsize particles (Fig. 3a). Clay coatings often have a globular appearance, but high magnification showed that they are composed primarily of individual, equant, flat, platy particles $\sim 100-500 \mathrm{~nm}$ diameter (Fig. 3b). Occasional elongated particles also were observed. EDS analysis of the fine-grained particles revealed a dominance of $\mathrm{Si}$ and $\mathrm{Al}$ in roughly equal proportions, consistent with their identification as a kaolin mineral and with the XRD analysis of the clay fraction as being kaolinitedominant.

The ufue sample also showed individual sand grains bound together by globular aggregates of clay. In some cases, the clay was observed to coat relatively fresh surfaces of feldspar (Fig. 3c). Higher magnification revealed that the coatings consisted of spherical microaggregates about $5 \mu \mathrm{m}$ diameter and consisted of radiallyarranged tube-like or lath-like particles that imparted a pin-cushion appearance to the micro-aggregate as a whole (Fig. 3d). Individual particles are 1-2 $\mu \mathrm{m}$ long and

Table 7 Full pattern fitting mineral analysis (wt. \%) of bulk geophagic soils

\begin{tabular}{|c|c|c|c|c|c|c|c|c|c|c|c|}
\hline \multirow[t]{2}{*}{ Mineralogy } & \multicolumn{5}{|c|}{ Udongo } & \multicolumn{2}{|c|}{ Ufue } & \multicolumn{3}{|c|}{ Vitango pepeta } & \multirow{2}{*}{$\begin{array}{l}\text { Mchanga } \\
838\end{array}$} \\
\hline & 818 & 832 & 835 & 839 & 849 & 833 & 845 & 834 & 812 & 842 & \\
\hline Quartz & 88.2 & 85.8 & 76.0 & 90.2 & 68.6 & 47.9 & 70.0 & 35.2 & 3.5 & 18.4 & 91.8 \\
\hline Plagioclase & 0.0 & 0.2 & 0.7 & 0.0 & 0.1 & 2.3 & 0.0 & 0.1 & 0.0 & 0.0 & 0.0 \\
\hline K-feldspar & 2.4 & 1.0 & 1.4 & 0.6 & 0.5 & 11.6 & 0.0 & 1.7 & 0.0 & 0.0 & 1.4 \\
\hline Calcite & 0.0 & 0.6 & 4.4 & 0.0 & 0.0 & 0.0 & 0.0 & 0.0 & 0.0 & 0.0 & 3.5 \\
\hline Hematite & 0.0 & 0.0 & 0.0 & 0.0 & 0.0 & 0.0 & 0.0 & 1.6 & 0.0 & 0.0 & 0.0 \\
\hline Goethite & 0.0 & 0.0 & 0.0 & 0.0 & 2.0 & 0.0 & 0.0 & 3.6 & 1.8 & 0.4 & 0.0 \\
\hline Gibbsite & 0.0 & 0.6 & 0.0 & 0.0 & 0.5 & 0.4 & 0.0 & 0.4 & 0.0 & 0.4 & 0.0 \\
\hline Kaolin/smectite? & 1.0 & 2.6 & 4.2 & 2.8 & 4.2 & 4.6 & 0.0 & 18.1 & 44.2 & 20.9 & 0.4 \\
\hline Kaolinite & 5.0 & 4.4 & 10.1 & 3.0 & 14.3 & 8.6 & 23.4 & 25.1 & 21.3 & 21.4 & 1.2 \\
\hline Halloysite & 3.3 & 4.9 & 3.2 & 3.3 & 9.8 & 24.7 & 6.6 & 14.3 & 29.1 & 38.5 & 1.7 \\
\hline Total-clay & 9.3 & 11.9 & 17.5 & 9.1 & 28.3 & 37.9 & 30.0 & 57.5 & 94.6 & 80.8 & 3.3 \\
\hline
\end{tabular}

Total-clay is sum of kaolin/smectite, kaolinite, and halloysite 

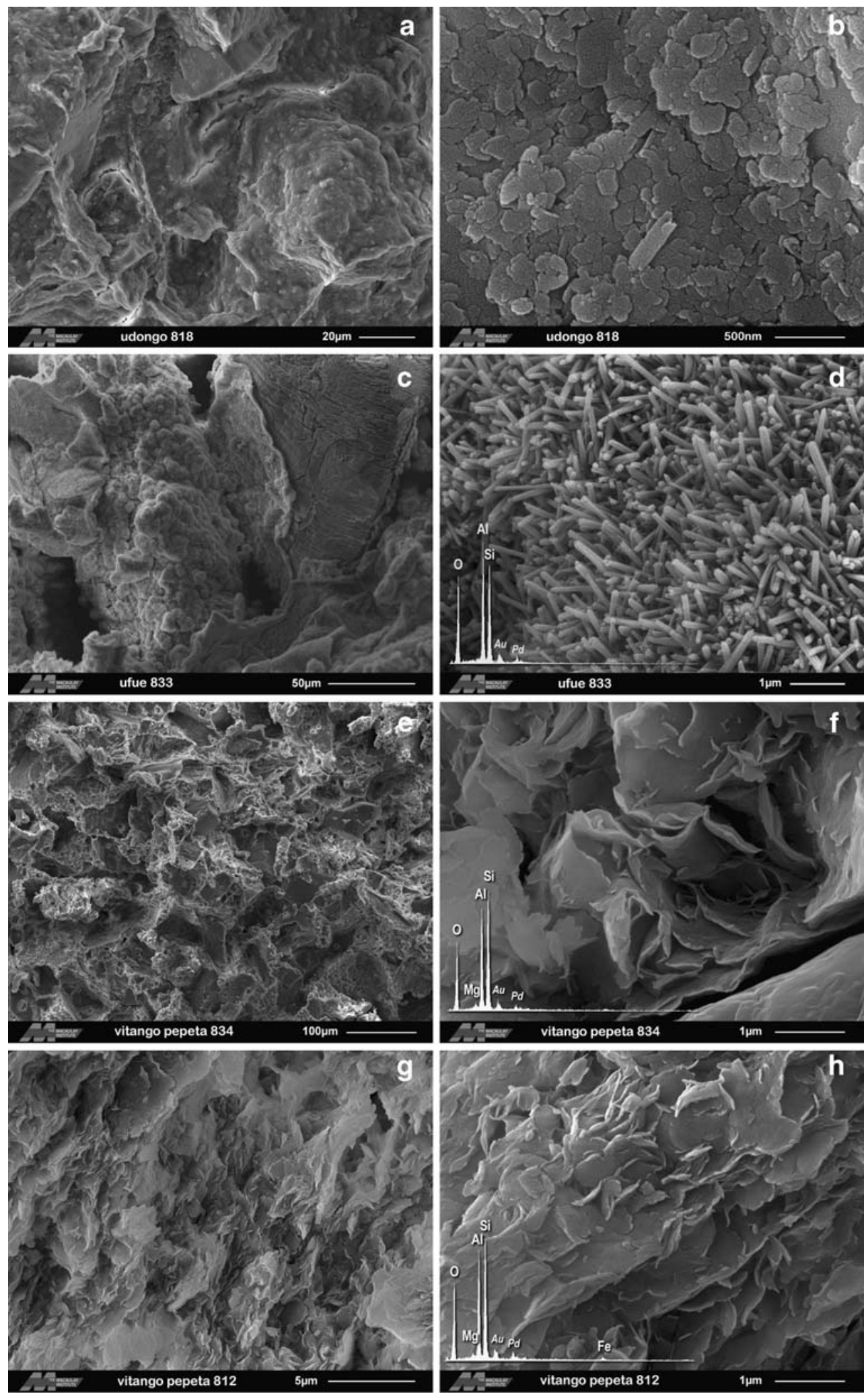

Fig. 3 SEM images and EDS spectra of selected samples a: Udongo (818) showing aggregated clay coating and binding sand particles together. b: Udongo (818) showing platy morphology and small size of constituent particles. c: Ufue (833) showing clay layer with globular morphology coating relatively unweathered feldspar grain. d: Ufue (833) showing delicate tubular morphology of halloysite with a pure $\mathrm{Al}, \mathrm{Si}$,

and O composition. e: Vitango pepeta (834) showing open sandy texture and binding network of clay. f: Vitango pepeta (834) showing crinkled mass of platy clay particles containing minor $\mathrm{Mg}$ in their composition. $\mathbf{g}$ : Vitango pepeta (812) showing aggregated clay texture. H: Vitango pepeta (812) showing crinkled platy morphology and curled edges of constituent clay particles, also containing minor $\mathrm{Mg}$ in their composition 
$\sim 0.2 \mu \mathrm{m}$ diameter. The morphology of these particles is identical with that of tubular halloysite. Identification as halloysite is consistent with both the EDS analysis that showed $\mathrm{Si}$ and $\mathrm{Al}$ in equal proportions, and with the XRD analysis of the clay fraction.

The two vitango pepeta samples examined by SEM had somewhat different clay contents and, according to both clay fraction and bulk sample XRD analyses, also differed in the relative importance of kaolinite, halloysite, and mixed-layer kaolin. Sample 834 was kaolinitedominant whereas sample 812 appeared to consist mainly of mixed-layer kaolin/smectite of halloysitic character with respect to the formamide test. Low magnification SEMs of 834 showed sandy material with abundant pore space held together by a meshwork of clay coatings over relatively fresh quartz and feldspar grains (Fig. 3e). The clay itself was composed of a crinkled mass of flat, platy particles, often with curled edges, about 1-2 $\mu \mathrm{m}$ diameter (Fig. 3f). There was abundant micro-pore space between the platy particles. The clay-rich nature of sample 812 is evident from low magnification SEMs, the whole consisting of crinkled flakes and aggregates arranged in subparallel fashion and with abundant void space (Fig. 3g). The constituent particles were mostly of an equant, platy shape, often bent or sinuous with curled edges, and ranged from $\sim 0.5$ to $2 \mu \mathrm{m}$ diam (Fig. $3 \mathrm{~h}$ ). These crinkled, curled, and sinuous morphologies lend support to the identification by XRD of kaolin/smectite in the vitango pepeta samples. Furthermore, in both samples EDS analysis showed that the composition of the clay particles may be different from those described for ufue and udongo above in that they have a slightly higher $\mathrm{Si}: \mathrm{Al}$ ratio and minor, but obvious, $\mathrm{K}, \mathrm{Mg}$, and $\mathrm{Fe}$ contents. Although minor in amount, the presence of $\mathrm{Mg}$ in the vitango pepeta clay particles is significant because it is consistent with the relatively high $\mathrm{MgO}$ content of the bulk vitango pepeta samples as determined by XRF (Table 4).

\section{Discussion}

In general, the geophagic soils we analyzed were highly variable in color and chemical composition, and had low concentrations of trace elements. The sole commonality was the presence of a kaolin mineral. Geophagy was practiced almost uniquely by pregnant women and young children.

No respondents described eating earth as a response to hunger or because other food was not available (Table 1). There was no significant difference in economic status or food intake between geophagists and non-geophagists (Young 2008). Therefore, hunger does not explain geophagy in this population.
The hypothesis that geophagy is practiced to supplement micronutrients suggests that color, particularly the common reddish hue indicative of iron found in many geophagic materials, may act as a primary or secondary stimulus in this respect (Wilson 2003). However, the Pemban geophagic soils are a variety of colors, ranging from white to red through various shades of yellow and brown. Geophagic soil selection based on color is thus not supported by our findings.

A second piece of evidence against the micronutrient deficiency hypothesis is the highly variable major chemical composition of the geophagic soils. Ufue and vitango pepeta soils are extremely low in $\mathrm{Ca}(<0.2 \%$ $\mathrm{CaO})$, whereas the concentration in udongo soils is variable. Indeed, the correlation of $\mathrm{CaO}$ with calcite in udongo samples from house walls suggests that the $\mathrm{CaO}$ content is a result of lime addition during construction, rather than a property of the original soil. As for Fe, the vitango pepeta samples are notably rich in this element (1.6-8.1\% $\mathrm{Fe}_{2} \mathrm{O}_{3}$ ), whereas all of the other soils, with one exception, are poor $\left(<1 \% \mathrm{Fe}_{2} \mathrm{O}_{3}\right)$.

Furthermore, the concentrations of trace elements of biological significance in the soils are uniformly low when compared to the usual range found in all types of mineral soils. It is difficult to conceive that such a negative similarity could act as stimulus to the selection of soils to be consumed. Furthermore, micronutrient cravings have yet to be identified in humans (Johns and Duquette 1991).

Our research would be strengthened by determining the bioavailability of these trace elements. However, it is probable that none of them is bioavailable to any significant extent because of the highly weathered nature of the soils. Weathering tends to remove mobile or "available" nutrients leading to a highly leached soil where any nutrient elements are associated with resistant minerals not susceptible to decomposition. Furthermore, the dominant mineral form of $\mathrm{Fe}$ is goethite, which is the least soluble of any of the common iron oxide minerals (Schwertmann and Taylor 1989). It seems unlikely that geophagists are regularly obtaining any mineral nutrients from these soils.

It has been suggested that geophagic soils are selected because of their pleasant unctuous texture associated with richness in clay (Wilson 2003). Clayey soils are consistent with the protection hypothesis; a number of clays have been proven efficacious at quelling gastro-intestinal distress and detoxifying harmful pathogens and chemicals (Gonzalez et al. 2004; Leonard et al. 1994; Theodorou et al. 1994). However, our data show that the texture of these soils is extremely diverse ranging from sand, i.e., udongo and mchanga materials that consist predominantly of quartz, to clay i.e., vitango 
pepeta largely made up of clay minerals. The ufue soils form an intermediate group between these two extremes. Selection of these geophagic soils simply on the basis of overall clay mineral content is not supported by the findings presented here, although it is notable that the four Swahili names are obviously correlated with total clay mineral content as determined by XRD.

Despite the many differences, the samples have one similarity: clay mineralogy. All clay fractions are dominated by a kaolin-type mineral, either kaolinite, halloysite, or a mixture of both. Additionally the vitango pepeta samples contain a significant amount of kaolin/smectite. Thus, it seems that the dominant type of kaolin mineral in the Zanzibar geophagic soils could be kaolinite, halloysite, or kaolin/smectite. This mineralogical similarity is consistent with the protection hypothesis, given that kaolin minerals have long been used in pharmaceutical formulations to both treat the causes and the symptoms of gastrointestinal distress (Vermeer and Ferrell 1985; Wakibara et al. 2001; Carretero 2002). The beneficial role of the kaolin minerals is based upon their ability to coat and adhere to the gastric and intestinal mucus membrane, thus protecting against toxins, bacteria, and viruses, and adsorbing excess water in the feces. (Allen and Leonard 1985; Leonard et al. 1994; Theodorou et al. 1994; Gonzalez et al. 2004).

It is plausible that the occurrence of kaolin-type minerals in all Zanzibari geophagic soil samples serves to protect the health of the consumer. The high prevalence of geophagy during pregnancy and early childhood, the times during which individuals experience the greatest biological vulnerability, lends support to this hypothesis. However, future analyses of Pemban soils must include mineralogical analysis of those not eaten, to ascertain that the clay mineralogy of all soils in Pemba is not dominated by kaolin.

No one has yet elucidated a mechanism by which humans can identify the presence of kaolin minerals in soils. One clue perhaps is the importance of smell in the selection of geophagic materials. The scent of earth, especially when wet, has been mentioned by many geophagists around the world (Hooper and Mann 1906; Forsyth and Benoit 1989; McIntyre 2000). Further study of human's capacity to identify and distinguish between odors of different clay minerals could be done easily, and may contribute further to our understanding of the selection and function of geophagy.

In summary, the geophagic soils of Pemba Island are diverse in color, texture, major element chemistry, and clay mineral content. The trace element contents of the soils, whether of biological or non-biological significance, are uniformly low, and the bioavailability of those that are present is dubious. The two commonalities observed among these soils is the dominance of kaolin in the clay fraction and the practice of geophagy by those who are biologically vulnerable. The palliative, protective and detoxifying properties of kaolin lend support to the hypothesis that geophagy is a protective behavior.

Acknowledgements We gratefully acknowledge financial support from Cornell University's Einaudi Center for International Studies and the National Institutes of Health (TG \#5T32 HD007331). We thank the Public Health Laboratory-IdC, the field staff and the Pemban participants in the study for their contributions to this research. This manuscript was improved through discussions about geophagy with Hajji Mohammed Hajji, Sabra Khalfan, Julius Lucks, Dennis Miller, Gretel Pelto, Paul Sherman, and Kathleen Rasmussen. S. Hillier acknowledges the support of the Scottish Executive Environment and Rural Affairs Department (SEERAD).

Open Access This article is distributed under the terms of the Creative Commons Attribution Noncommercial License which permits any noncommercial use, distribution, and reproduction in any medium, provided the original author(s) and source are credited.

\section{References}

Allen, A. and LeONARD, A. 1985. Mucus structure. Gastroenterol Clin. Biol. 9(12 Pt 2):9-12.

Anell, B. and Lagercrantz, S. 1958. Geophagical Customs. Uppsala University, Uppsala.

Aufreiter, S., Hancock, R., Mahaney, W., Stambolic-robB, A., and SANMUGADAS, K. 1997. Geochemistry and mineralogy of soils eaten by humans. Int. J. Food Sci. Nutr. 48:293-305.

Aufreiter, S., Mahaney, W., Milner, M. W., Huffman, M., HANCOCK, R., WINK, M., and REICH, M. 2001. Mineralogical and chemical interactions of soils eaten by chimpanzees of the Mahale Mountains and Gombe Stream National Parks, Tanzania. J. Chem. Ecol. 27:285-311.

CARretero, M. 2002. Clay minerals and their beneficial effects upon human health. A review. Appl. Clay Sci. 21:155-163.

Churchman, G. J., Whitton, J. S., Claridge, G. G. C., and Theng, B. K. G. 1984. Intercalation method using formamide for differentiating halloysite form kaolinite. Clays Clay Miner 32:241-248.

Clark, J. D. 2001. Kalambo Falls Prehistoric Site (Vol. 3). Cambridge University Press, London.

FESSLER, D. 2002. Reproductive immunosuppression and diet. Curr. Anthropol. 43:19-60.

FLAXMAN, S. and SHERMAN, P. 2000. Morning sickness: a mechanism for protecting mother and embryo. Q. Rev. Biol. 75:113-148.

FORMBY, B. 1995. Immunologic response in pregnancy. Its role in endocrine disorders of pregnancy and influence on the course of maternal autoimmune diseases. Endocrinol. Metab. Clin. North Am. 24:187-205.

Forsyth, C. and BenOIT, G. M. 1989. "Rare, Old, Dirty Snacks": some research notes on dirt eating. Deviant Behav. 10:61-68.

GoldschmidT, V. M. 1954. Geochemistry. Clarendon Press, Oxford.

Gonzalez, R., De Medina, F. S., Martinez-Augustin, O., Nieto, A., Galvez, J., Risco, S., and Zarzuelo, A. 2004. Antiinflammatory effect of diosmectite in hapten-induced colitis in the rat. Br. J. Pharmacol. 141:951-960.

HiLliER, S. 1999. Use of an air brush to spray dry samples for X-ray powder diffraction. Clay Miner. 34:127-135. 
HiPPOCRATES. 1849. The Genuine Works of Hippocrates. Adams F, translator. London: Printed for the Sydenham society.

HoOPER, D. and MANN, H. H. 1906. Earth-eating and the earth-eating habit in India. Memoirs Asiatic Soc. Bengal 1:249-273.

HunTER, J. M. 1973. Geophagy in Africa and in the United States: a culture-nutrition hypothesis. Geogr. Rev. 63:170-195.

ITAMI, K. and FUJITANI, H. 2005. Charge characteristics and related dispersion/flocculation behavior of soil colloids as the cause of turbidity. Colloid Surface A 265:55-63.

JoHNS, T. 1986. Detoxification function of geophagy and domestication of the potato. J. Chem. Ecol. 12:635-646.

Johns, T. and DuQuetTe, M. 1991. Detoxification and mineral supplementation as functions of geophagy. Am. J. Clin. Nutr. $53: 448-456$

Jones, R. and HANSON, H. C. 1985. Mineral Licks, Geophagy, and Biogeochemistry of North American Ungulates. Iowa State Press, Ames.

KREULEN, D. A. 1985. Lick use by large herbivores: a review of benefits and banes of soil consumption. Mammal. Rev. 15:107123.

KRISHNAMANI, R. and MAHANEY, W. 2000. Geophagy among primates: adaptive significance and ecological consequences. Anim. Behav. 59:899-915.

LAufer, B. 1930. Geophagy. Field Museum of Natural History, Chicago.

Leake, B. E., Hendry, G. L., Kemp, A., Plant, A. G., Wilson, J. R., Coats, J. S., Aucott, J. W., Lunel, T., and Howarth, R. J. 1969. The chemical analysis of rock powders by automatic x-ray fluorescence Chem. Geol. 5:7-86.

Leonard, A., Droy-LefaiX, M. T., and Allen, A. 1994. Pepsin hydrolysis of the adherent mucus barrier and subsequent gastric mucosal damage in the rat: effect of diosmectite and 16,16 dimethyl prostaglandin E2. Gastroenterol. Clin. Biol. 18:609616

MahaneY, W., HANCOCK, R., and InOUE, M. 1993. Geochemistry and clay mineralogy of soils eaten by Japanese macaques. Primates 34:85-91.

Mahaney, W. C., Aufreiter, S., and Hancock, R. 1995a. Mountain gorilla geophagy: a possible seasonal behavior for dealing with the effects of dietary changes. Int. J. Primatol. 16:475-487.

Mahaney, W. C., Stambolic, A., KnezeVich, M., Hancock, R. G. V., Aufreiter, S., SANMUGadAs, K., Kessler, M. J., and GrYNPAS, M. D. 1995b. Geophagy amongst Rhesus Macaques on Cayo Santiago, Puerto Rico. Primates 36:323-333.

Mahaney, W., Milner, M. W., Sanmugadas, K., Hancock, R., Aufreiter, S., Wrangham, R., and Pier, H. W. 1997. Analysis of geophagy soils in Kibale Forest, Uganda. Primates 38:159-176.

MCINTYRE, P. 2000. "That Dirt Was Good!”: memories of geophagy among Alabama black belt tenant farmers. Tributaries 3:59-74.

Middleton, J. 2004. African Merchants of the Indian Ocean: Swahili of the East African Coast. Waveland, Long Grove.

MitchelL, R. L. 1964. Trace elements in soils, pp. 320-368, in: F. E. Bear (ed.). Chemistry of the Soil. Reinhold Publishing Corporation, New York.

Moore, K. L. and Persaud, T. V. N. 1998. The developing human: clinically oriented embryology. Saunders, Philadelphia.

NoRRISH, K. and HutTON, J. T. 1969. An accurate X-ray spectrographic method for the analysis of a wide range of geological samples. Geochim. Cosmochim. Ac. 33:431-453.
Omotoso, O., Mccarty, D. K., Hillier, S., and Kleeberg, R. 2006. Some successful approaches to quantitative mineral analysis as revealed by the 3rd Reynolds Cup contest. Clays Clay Miner. 54:748-760.

PeECH, M. E. 1965. Hydrogen ion activity, pp 914-926, in: C. A. Black, D. D. Evans, J. L. White, L. E. Ensminger, F. E. Clark (eds.). Methods of Soil Analysis. v.2. Chemical and Nicrobiological Properties. American Society of Agronomy, Madison.

ProfET, M. 1992. Pregnancy sickness as adaptation: A deterrent to maternal ingestion of teratogens, pp. 327-366, in J. H. Barkow, L. Cosmides, J. Tooby (eds.). The Adapted Mind: Evolutionary Psychology and the Generation of Culture. Oxford University Press, New York.

SCHWERTMANN, U. and TAYLOR, R. M. 1989. Iron oxides, pp. 380 428, in J. B. Dixon, S. B. Weed, R. C. Dinauer (eds.). Minerals in Soil Environments. Soil Science Society of America, Madison.

SIMJEE, S. 2007. Foodborne Diseases. Humana, Totowa.

SMITH, J. C. and HALSTED, J. A. 1970. Clay ingestion (geophagia) as a source of zinc for rats. J. Nutr. 100:973-980.

Smith, B., Chenery, S. R. N., Cook, J. M., Styles, M. T., Tiberindwa, J. V., Hampton, C., Freers, J., RutakingGirwa, M., Sserunjogi, L., Tomkins, A., and Brown, C. J. 1998. Geochemical and environmental factors controlling exposure to cerium and magnesium in Uganda. J. Geochem. Explor. 65:1-15.

STOCKLEY, G. M. 1942. The geology of the Zanzibar protectorate and its relation to the east African mainland. Geol. Mag. 79:233-240.

Theodorou, V., Fioramonti, J., Droy-lefaiX, M. T., Plique, O., and BUENO, L. 1994. Protective action of diosmectite treatment on digestive disturbances induced by intestinal anaphylaxis in the guinea-pig. Aliment. Pharmacol. Ther. 8:295-299.

VERMEER, D. and FERRELL, R. J. 1985. Nigerian geophagical clay: a traditional antidiarrheal pharmaceutical. Science 227:634-636.

VON BONSDORFF, B. 1977. Pica: a hypothesis. Br. J. Haematol. 35 (3):476-477.

Wakibara, J., Huffman, M., Wink, M., Reich, S., Aufreiter, S., HANCOCK, R., Sodhi, R., MahaneY, W., and Russel, S. 2001. The adaptive significance of geophagy for Japanese macaques (Macaca fuscata) at Arashiyama, Japan. Int. J. Primatol. 22:495-520.

WILEY, A. S. and KATZ, S. H. 1998. Geophagy in pregnancy: a test of a hypothesis. Curr. Anthropol. 39:532-545.

WiLSON, M. J. 1987. X-ray powder diffraction methods, pp. 26-98, in M. J. Wilson (ed.). A Handbook of Determinative Methods in Clay Mineralogy. Blackie \& Son, Glasgow and London.

WILSON, M. J. 2003. Clay mineralogical and related characteristics of geophagic materials. J. Chem. Ecol. 29:1525-1547.

YouNG, S. L. 2008. A biocultural study of the relationship between pica and anemia. Cornell University, Ithaca, $300 \mathrm{p}$.

YounG, S. and ALI, S. 2005. Linking traditional treatments of maternal anaemia to iron supplement use: an ethnographic case study from Pemba Island, Zanzibar. Matern. Child Nutr. 1:51-58.

Young, S., Wilson, M., Miller, D., and Hillier, S. 2008. Toward a comprehensive approach to the collection and analysis of pica substances, with emphasis on geophagic materials. PLOS ONE 3: e3147.

YuAN, J. and MuRRAY, H. H. 1997. The importance of crystal morphology on the viscosity of concentrated suspensions of kaolins. Appl. Clay Sci. 12:209-219. 